\title{
HIV heterosexual transmission to stable sexual partners of HIV-infected brazilian hemophiliacs
}

\author{
Hemophilia Unit, Hospital Brigadeiro, São Paulo State Health Department and the Immunogenetics and \\ Experimental Transplantation Laboratory, LIM 56, College of Medicine, São Paulo University - São Paulo, Brazil
}

\begin{abstract}
Nineteen Brazilian HIV-infected hemophiliacs and their stable heterosexual sexual partners were studied with the aim of assessing the rate of HIV transmission in this at risk group. The mean length of relationship between couples was 7.4 years. The hemophiliac men were Class II $(n=6)$, III $(n=11)$ and IVa $(n=2)$ of the CDC classification. They had decreased CD4+ and elevated CD8+ cell numbers; five had p24 antigenemia. We found 3 HIV-infected women ( 15.8 percent) by routine and confirmatory tests, a prevalence similar to that seen in other countries. They were asymptomatic and had no detectable p24 antigenemia. The 3 seropositive women's partners were Class II and III-CDC, and had normal CD4+ and CD8+ values and no p24 antigenemia. All seronegative women also had normal CD4+ and CD8+ numbers, except for elevated CD8+ cells in three of them, but immune abnormalities had already been seen in some seronegative partners at high risk for HIV infection. Our results reinforce previous suggestions that heterosexual transmission to stable female partners occurs preferentially early after initiation of sexual exposure, and possibly when the transmitter has high levels of viremia and regular sexual activity.
\end{abstract}

UNITERMS: HIV Infection, heterosexual transmission, hemophilia, CD4+ lymphocyte.

\section{INTRODUCTION}

$\mathrm{B}$ razilian hemophiliacs who received coagulation factor concentrates from 1980 to 1985 are at high risk for acquiring HIV. This high-risk group has rates of HIV infection in Brazil and other countries that reach 50 percent or higher. ${ }^{1-3}$ Studies in this group usually report rates of heterosexual transmission to their partners of 10-20 percent. ${ }^{4.5}$ Although Brazil is ranked fourth in the world in number of AIDS patients, there is no data on

\author{
Address for correspondence: \\ Alberto José da Silva Duarte \\ Faculdade de Medicina - USP \\ Av. Dr. Arnaldo, 455, sala 105A - Cerqueira César \\ São Paulo/SP - Brasil - CEP 01246-903
}

the clinical course of Brazilian HIV-infected hemophiliacs and their role as heterosexual transmitters.

Here we show the immunologic parameters of 19 patients from a hematology center in São Paulo: 14 with hemophilia A and 5 with hemophilia B (age range, 21-54 years); and their stable female sexual partners (18-49 years). Results were compared to 15 normal adult subjects (controls) studied at the same time. The mean length of relationship was 7.4 years, and all couples denied using condoms before this study. The sexual partners had no other known risk factors for HIV.

The HIV-infected hemophiliacs were Class II $(n=6)$, III $(n=11)$ and IVa-CDC $(n=2)$. Five of them had peripheral blood CD4+ cells below 400/l: 3 Class III and 2 Class IVa patients; mean CD4+ cell counts of the patients were significantly lower compared to the controls (Fig. 1). Their CD8+ cell count was higher than the controls in 7 (64 percent) and 2 ( 33 percent) of the class III and II patients, 


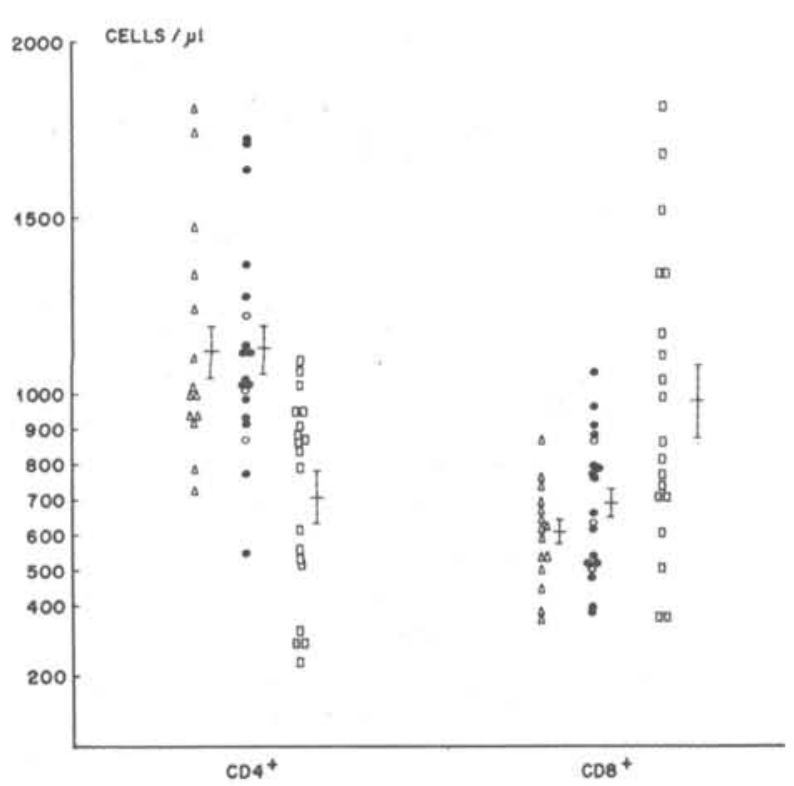

Figure 1-CD4+ and CD8+ peripheral blood lymphocytes enumeration from hemophiliacs $(\bullet, n=19)$, their female sexual partners $(\bullet, n=19)$ and 15 healthy subjects as controls (D). Empty circles represent results of the three HIV-infected women. Bars represent means and standard errors. Data was analyzed through analysis of variance and the means of the groups compared with the NeulmanKeus test. CD4+ and CD8+ mean values of hemophiliacs were significantly different $(p<0.05)$ from those of the female partners and controls. Methodology: indirect immunofluorescence with monoclonal antibodies.

respectively. Mean CD8+ cell counts of patients were significantly higher compared to the controls (Fig. 1). Five patients had p24 antigenemia: 3 of them were Class III and 2 Class IVa-CDC. Hypergammaglobulinemia $(1.6 \mathrm{~g} / \mathrm{dl})$, due to high $\mathrm{IgG}$ and $\mathrm{IgA}$ levels, was seen in 18 of the 19 patients (Fig. 2).

Of the 19 asymptomatic sexual partners, three (15.8 percent) were seropositive for HIV by ELISA and Western blot assays. They were classified CDC Class II. None of them showed the seric p24 antigen. The CD4+ cell counts were within normal ranges in most partners, including the three seropositive women (Fig. 1). The three seronegative partners showed an elevated number of CD8+ cells, but the mean CD8+ count of the partners' group was similar to the controls (Fig. 1). IgG levels were normal in all but four women; two of them were seropositive (Fig. 2). IgM and $\operatorname{IgA}$ levels were within normal ranges.
The three hemophiliacs whose partners were infected had CD4+ cell counts above 500/ul (536, 902 and 608/ul, respectively), and elevated CD8+ numbers (1421, 1516 and $1105 / \mathrm{ml}$, respectively). They were at Stages II, II and III-CDC, respectively, and had no p24 antigenemia.

The heterosexual transmission rate of Brazilian hemophiliacs to their female partners, 15.8 percent after a mean relationship of 7.4 years (2.1 per 100 person years), is similar to that of other countries. Some authors could associate an increased risk of male-to-female transmission to factors related to the transmitter, such as: more advanced stages of disease; more prolonged time of exposure; or more pronounced laboratory abnormalities..$^{4-6}$ Of the latter, a decrease in peripheral CD4+ cell numbers and the presence of p24 antigenemia are particularly important. However, another study ${ }^{9}$ showed that transmission preferentially occurred at an earlier time after

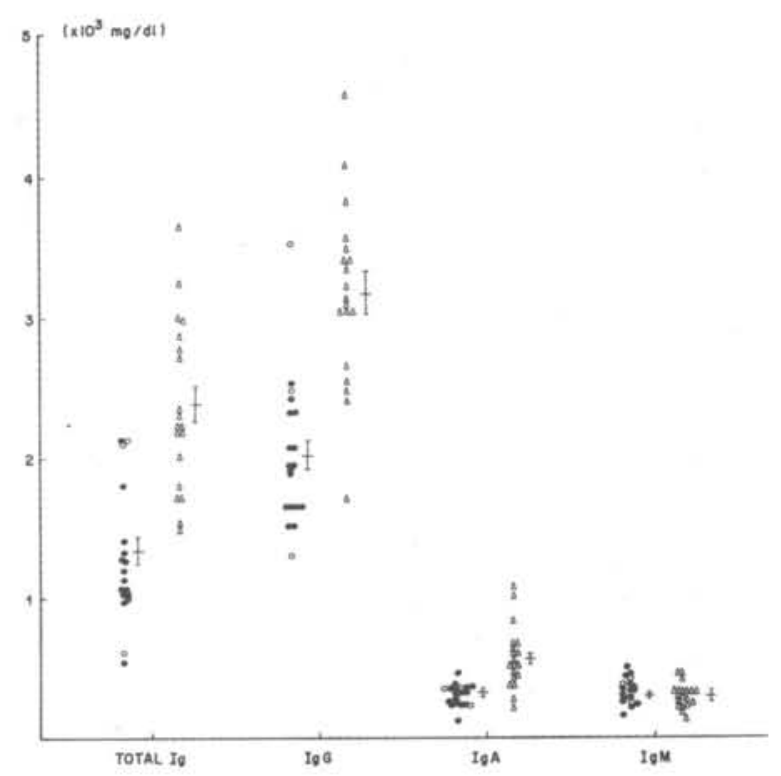

Figure 2 - Total and Ig classes determinations in hemophiliacs $(\bullet, n=19)$ and their female sexual partners $(\bullet, n=19)$. Empty circles represent results of the three HIV-infected women. Bars represent means and standard errors. Mean values and standard errors for 15 controls were: total Ig: $1.04 \pm 0.2 \mathrm{~g} / \mathrm{dl} ; \operatorname{lgG}: 1.55 \pm 0.386 \mathrm{~g} / \mathrm{dl} ; \lg A ; 0.317 \pm 0.102 \mathrm{~g} / \mathrm{dl} ; \operatorname{IgM} ; 0.279$ $\pm 0.113 \mathrm{~g} / \mathrm{dl}$. Differences were significant $(p<0.05)$ for total $\mathrm{lg}, \lg \mathrm{g}$, and IgA levels between hemophiliacs and sexual partners, and between hemophiliacs and controls. Statistical analysis was done as in the Figure 1 legend. Differences between sexual partners and controls were significant only for IgG levels $(p<0,05)$. Methodology: Laser nephelometry. 
initiation of sexual exposure (median of 10.4 months). Transmission at later periods was considered improbable. These results were related to the fact that the immune evaluation was performed at the presumed period of transmission, and not after, as in other studies. The three hemophiliacs who infected their sexual partners had normal CD4+ cell counts, elevated CD8+ cells, and p24 antigenemia. This result would be in accordance with the assumption of an early transmission. We could not evaluate, however, the influence of sexual practices in the transmission rate. The fact that transmission occurs early may also indicate that transmittibility could be related to the virus burden of the transmitter. Serum titers of HIV are high shortly after infection occurs, low during asymptomatic stages, and rise again when disease develops (at this stage sexual activity is usually compromised). ${ }^{?}$

The three infected partners were asymptomatic, p24 antigen negative and had preserved lymphocyte subpopulations. The only abnormal laboratory feature was elevated levels of IgG in two of the women. None had a mono-like syndrome. It is noteworthy, however, that we did find some laboratory abnormalities in the HIVseronegative partners, namely, elevated CD8+ cell numbers and hypergammaglobulinemia. Similar findings were noted by other authors, ${ }^{8}$ who suggested the participation of other infections in the genesis of these findings.
Alternatively, the presence of HIV particles or fragments in the serum of HIV-negative sexual partners has been documented, raising the possibility of the existence of HIV-infected seronegative persons. This possibility has been discarded by others authors who have demonstrated the absence of HIV infection in seronegative persons at high risk. ${ }^{9.10}$ They hypothesized that such seronegative sexual partners were exposed to fragments of the virus, thus becoming reactive to assays that detect the virus or its fragments. Alternatively, it has been suggested that some individuals at risk for the infection could mount an effective immune response against the virus based on a predominant T-helper-1 immune response."

We conclude that the Brazilian HIV-infected hemophiliacs studied here show features similar to those of other countries, and behave as important heterosexual transmitters.

\section{ACKNOWLEDGMENTS}

We thank Danilo F. Nunes and Luis F. M. Brígido for crucial advice.

\section{RESUMO}

Introdução e Objetivos: Pacientes hemofílicos no Brasil apresentaram alto risco de adquirirem infecção pelo HIV devido a transfusōes no periodo de 1980-86. Entretanto, não há relatos publicados em nosso país acerca da evolução clínica destes pacientes, nem sobre sua importância como transmitteres heterossexuais. Metodologia: Foram estudados 19 pacientes hemofilicos infectados pelo HIV e suas respectivas parceiras sexuais fixas, e 15 individuos normais como controles. No momento do estudo, 6 dos pacientes eram do grupo II (CDC, 1986), 11 do grupo III e 2 do grupo IVa. O tempo médio de relacionamento dos casais foi de 7,4 anos. A infecção pelo HIV foi diagnosticada pelas técnicas ELISA e Western-blot e presença de antigenemia (p24) por ELISA comercial. A avaliação imunológica consistiu na determinação de linfócitos CD4 e CD8 do sangue periférico por imunoflorescência indireta com anticorpos monoclonais e na dosagem de lg total, IgA, lgG e IgM séricos por nefelometria. Resultados: O grupo de pacientes apresentava medianas das contagens de células CD4 e CD8 diminuidas quando comparadas ao grupo controle; 5 dos pacientes eram p24 positivos. Da mesma forma que em outras casuísticas, $15,8 \%(3 / 19)$ das parceiras eram soropositivas para o HIV, encontrando-se assintomáticas e p24 negativas. Seus respectivos parceiros eram grupo II ou III-CDC, apresentavam números normais de células CD4 e CD8, e eram p24 negativos. As parceiras soronegativas apresentavam contagens normais de células CD4 e CD8, com exceção de 3 delas que apresentavam células CD8 aumentadas. Entretanto, alteraçōes imunológicas já foram foram descritas em parceiras sexuais soronegativas de pacientes HIV positivos. Conclusōes: Nossos resultados corroboram sugestōes prévias de que a transmissão heterossexual a parceiras sexuais fixas parece ocorrer precocemente após o início da exposiçāo sexual e possivelmente quando o parceiro apresenta altos índices de viremia e atividade sexual regular. 


\section{REFERENCES}

1. Mathez D, Leibovitch J, Sultan Y, Maisonneuve P. LAV/ HTLVIII seroconversion and disease in hemophiliacs in France. N Engl J Med 1986;314:118-9.

2. Ragni MV, Winklestein A, Kingsley LA, Spero JA, Lewis JH. Update of HIV seroprevalence, seroconversion, AIDS incidence, and immunlogic correlates of HIV infection in patients with hemophilia A and B. Blood 1987;70:786-90.

3. Zanichelli MA. Avaliação imunológica de pacientes hemofílicos. Thesis, College of Medicine, São Paulo University, Brazil, 1986.

4. Goedert JJ, Eyster ME, Biggar RJ, Blattner WA. Heterosexual transmission of HIV: association with severe depletion of the T-helper lymphocytes in men with hemophilia. AIDS Res Hum Retroviruses 1987;3:355-61.

5. Laurian Y, Peynet J, Verroust F. HIV infection in sexual partners of HIV seropositive patients with hemophilia. N Engl J Med 1989;320:183.

6. Saracco A, Musicco M, Nicolosi A, et al. Man-to-woman sexual transmission of HIV: a longitudinal study of 343 steady partners of infected men. J Acquir Immunodef Syndr 1993;6:497-502.

7. Ragni MV, Kingsley LA, Nimorvicz Gupta P, Rinaldo C. HIV heterosexual transmission in hemophilia couples: lack of relation to T4 number, clinical diagnosis, or duration of exposure. J Acquir Immunodef Syndr 1989;2:557-63.

8. Fischl MA, Dickinson GM, Scott GB, Klimas N, Fletcher MA, Parks W. Evaluation of heterosexual partners, children and household contacts of adults with AIDS. JAMA 1987;257:640-4.

9. Crawe SM, Elbeick T, Ulrich PP, Mills J, Moss A. Lack of evidence of occult human immunodeficiency virus in seronegative individuals at very high risk of infection. J Med Virol 1991;35:160-4.

10. Jackson JB, Kwok SY, Hopsicker JO, et al. Absence of HIV infection in antibody-negative sexual partners of HIVinfected hemophiliacs. Transfusion 1989;29:265-7.

11. Shearer GM, Clerici M. T-helper immune dysfunction in asymptomatic, HIV-1 seropositive individuals: the role of TH1-TH2 cross regulation. In: Coffman RL, ed. Regulation and Functional Significance of T-cell Subjects. Basel: Karger. Chem Immunol 1992;54:21-43.

\section{SPONSORSHIP}

This work was partially supported by LIM-HC. 